DOI: 10.46340/eppd.2021.8.2.4

\author{
Volodymyr Boiarskyi \\ ORCID ID: https://orcid.org/0000-0002-1291-0760 \\ Institute of Legislation of the Verkhovna Rada of Ukraine
}

\title{
PHENOMENOLOGY OF CROSS-BORDER COOPERATION AND ITS ROLE IN THE FUNCTIONING OF «EUROPE OF REGIONS»
}

\author{
Володимир Боярський \\ Інститут законодавства Верховної Ради України \\ ФЕНОМЕНОЛОГІЯ ТРАНСКОРДОННОГО \\ СПІВРОБІТНИЦТВА ТА ЙОГО РОЛЬ \\ У ФУНКЦІОНУВАННІ «СВРОПИ РЕГІОНІВ»
}

Cross-border cooperation is an important form of pan-European processes of integration cooperation, which from the very beginning was aimed at equalizing the regions of the member states of the Council of Europe in their economic and social development. This form of cooperation arose based on the peculiarities of the historical development of the European continent, the results of world wars and the emergence of new borders between states. This situation in fact often disrupted systemic ties between peoples living in former empires, while these ties in the long run remained in their mentality, national, linguistic, ethnic features and characteristics. However, these conditions promoted actualization of profile cooperation. Cross-border cooperation plays an important role in the regional policy of the European Community, which has been transformed into the European Union. Cross-border cooperation plays one of the most important roles in the concept of "Europe of Regions", because it increases and expands the competence of not only border but also subnational regions, as well as increasing the international legal personality of local governments of cross-border cooperation. An important element of the stable formation and development of cross-border cooperation is its regulatory framework, which allows not only adjacent regions of EU-Member States to participate in its implementation, but also other regions of third countries acting as Member States. The Council of Europe has signed the European Framework Convention on Transfrontier Cooperation between Territorial Communities or Authorities in 1980. The adoption by the Council of Europe in 1985 of the European Charter of Local Self-Government only strengthened the organizational, regulatory, managerial and resource capacity of cross-border cooperation between territorial communities or authorities within the European continent. The adoption by the Council of Europe of the two international legal acts of a treaty nature not only legalized the theoretical and practical developments of cross-border cooperation, but also contributed to the legalization of the basic principles of organization and functioning of the institution of local democracy in the member states of EU members (because they are all member states of the Council of Europe at the same time) and third countries that have declared their wish to join the EU as already member states of the Council of Europe. In the context of global informatization, cross-border cooperation between territorial communities or authorities acquires the characteristics of a system operating and developing on the basis of network properties, which, in turn, improves the cooperation in such a way: a) strengthens its collaborative capacity, b) involves new subjects outside its formal subject composition, operating in the regions and local authorities, in the cooperation, as well as c) forms a stable relativistic potential for development and improvement of the implementation of its teleological dominants.

Keywords: cross-border cooperation, "Europe of regions", subnational region, cross-border region, local government.

Постановка проблеми. Становлення в Україні системи місцевого самоврядування (далі MCB) є одним з найважливіших факторів становлення, розвитку і вдосконалення демократичної 
правової державності. Акцентуація публічної влади на самоорганізації жителів відповідних територій держави, які виступають як члени відповідних територіальних громад (далі- ТГ) і самостійно в умовах децентралізації вирішують питання місцевого значення в рамках Конституції та законів України (див. ст. 140 Конституції України ${ }^{1}$ ), - виступає могутнім стимулом та детермінантою локального розвитку і вдосконалення локальної системи реалізації і захисту прав і свобод людини, бо саме на локальному рівні функціонування соціуму конкретна людина не тільки здійснює свою правову соціалізацію, а й реалізує свій конституційно-правовий статус.

Разом $з$ тим, необхідно наголосити на тому, що локальне реформування публічної влади і локального розвитку не завжди і не скрізь проходить однаково і рівномірно. Такий стан справ обумовлений, по-перше, особливостями історичного, географічного та культурологічного характеру окремих територій держави (характерологічно-топосний критерій. - Авт.); по-друге, диспропорціями в їх економічному розвитку (економічно-релятивістський критерій. - Авт.); по-трете, місцем їх знаходження (локацією) на території держави (iї центр або периферія) (територіальноідентифікаційний критерій. - Авт.); по-четверте, складом їх населення (по віковому, статевому, освітньому, професійному та іншим ознакам) (структурно-демографічний критерій. - Авт.); по-п’яте, особливостями рис менталітету народів, що мешкають на території держави або суміжних держав (як результат неодноразової історичної ретроспективності зміни державних кордонів) (засадничорозумовий критерій. - Авт.); по-шосте, відповідними стереотипами індивідуальної, групової або колективної свідомості відносно своїх сусідів з прикордоння (стереотипно-свідомий критерій. Авт.), а також іншими особливостями розвитку і функціонування.

Отже, саме звідси актуалізується проблематика знаходження таких форм розвитку, що сприяли би нівелюванню або гармонізації наведених ознак з метою економічного, соціального і культурного зростання як територій, так і населення, що на них мешкає. До таких форм, безумовно, відноситься транскордонне співробітництво регіонів та місцевих влад і громад.

Аналіз останніх досліджень і публікацій. Треба наголосити на тому, що активізація процесів щодо осмислення та вивчення транскордонного співробітництва в рамках інтеграційних тенденцій в Європі розпочалась ще в 50-ті роки XX ст., піонерами в цьому питанні виступили німецькі вчені К. Дойч і Е. Хаaс.

У 60-ті роки XX ст. в Західній Європі пожвавлюються дискусії між прихильниками двох теоретичних підходів до європейської інтеграції: неофункціоналізму і міжурядового підходу. Неофункціоналізм пов'язував динаміку європейської інтеграції з соціальним контекстом модернізації, підйому технократії та глобалізації, в той час як міжурядовий підхід, не заперечуючи важливості зазначених факторів, відстоював ідею первинності реакцій держав-націй, які переважно визначаються конкурентної динамікою безладної міжнародної системи ${ }^{2}$. Отже, неофункціоналізм більш активно використовував можливості транскордонного співробітництва, хоча в межах міжурядового підходу воно також знаходило себе місце в контексті позитивного сприяння з боку національних урядів.

Теоретичні дискусії навколо інтеграції та транскордонного співробітництва продовжувались і в 70-ті роки XX ст. - саме з того часу європейська інтеграція розглядається як окремий випадок в дослідженнях міжнародних відносин, дослідження контекстуалізуються i концентруються на проблемних областях інтеграції, таких як окремі напрямки комунітарної політики, до яких відноситься і транскордонне співробітництво, а також відношення європейських політичних партій до інституту виборів в рамках Європейського співтовариства тощо.

У 80-ті роки XX ст. актуалізація профільних досліджень знижується, в цілому підтверджуючи ідею про «занепад» великих теорій інтеграції³.

Однак, доктринально-теоретична ситуація в області актуалізації досліджень європейської інтеграції принципово починає змінюватись з початку 90-х років ХХ ст., що детерміновано формуванням трьох основних напрямків теоретичний досліджень:

- «європеїзація» національних політик (трансформації політичних систем і політичних процесів держав-членів ЄС під впливом Свросоюзу);

\footnotetext{
${ }^{1}$ Конституиія України, 1996 (Верховна Рада України). Відомості Верховної Ради України, 30, 141.

${ }^{2}$ Бусыгина, И. М. (2001). Политическая роль регионов в структуре Европейского Союза: Концептуальные и прикладные аспекты: диссертация на соискание научной степени доктора политических наук. Москва: МГИМО МИД России.

${ }^{3}$ Lijphart, A., Karl, W. (1981). Deutsch and the New Paradigm in International Relations. In: Merritt, R., Russett, B. (eds) (1981). From National Development to Global Community. London, 235.
} 
- сутність комунітарних регламентації і регулювання;

- мережеве (багаторівневе) управління в Свропейському Союзі ${ }^{1}$.

Отже, саме на використанні напрацювань в області сутності комунітарних регламентації і регулювання базується феномен транскордонного співробітництва, а також дане дослідження.

У Радянському Союзі вивчення актуальних питань інтеграції, до яких відноситься i транскордонне співробітництво, починається пізніше, причому основний акцент був зроблений на іiі економічних аспектах. В останні роки суттєвий внесок у вивчення інтеграційної проблематики був зроблений радянськими фахівцями В. Барановським, Ю. Борко, О. Буторіною, Т. Зоновою, 3. Кузіною, М. Максимовою, О. Потемкіною, М. Стріжневою, А. Тевдоем-Бурмулі, В. Шемятенковим, В. Шенаєвим, Ю. Шишковим, Е. Хесіним та іншими.

Серед західних дослідників загальних проблем інтеграції, включаючи і транскордонне співробітництво, виділяються роботи Дж. Вейлера, В. Молле, Дж. Піндера, Г. Робертса, А. Сбраджа, Д. Сіджанскі, Ф. Уілсона, У. Уоллеса, М. Фуше, Ф. Шміттера. Дослідженню актуальних питань розвитку і модифікації політичних систем сучасних суспільств (в тому числі в в сфері становлення і розвитку регіональної політики держав-членів СС та самого СС) присвячено роботи Б. Андерсона, Ф. Броделя, Е. Гідденса, Р. Дарендорфа, А. Дебідура, К. Зонтхаймера, Д. Каванаха, А. Лейпхарта, Г. Манна, Р. Мьюра, Т. Ніппердея, Р. Паддісона, Т. Парсонса, Р. Патнема, С. Роккана, Е. Сміта.

До вітчизняних і зарубіжних досліджень в області регіоналізму і федералізму відносяться праці дослідників С. Артоболевського, М. Баймуратова, І. Балабанової, О. Батанова, С. Борисова, І. Бусигіної, Є. Василькової, Є. Васильєва, В. Гельмана, А. Дахіна, М. Долішнього, Т. Зонової, І. Іванова, М. Ільіна, А. Макаричева, С. Медведева, Н. Мікули, О. Морозової, Л. Смірнягіної, Т. Фадєєвої. У наукових працях В. Вакуленка, 3. Варналія, В. Воротіна, І. Дегтярьової, І. Криничної, В. Кампа, В. Куйбіди, Е. Лібанової, Ю. Макогона, П. Покатаєва, С. Романюка, В. Толкованова, В. Чужикова та інших розкрито сутність і різні аспекти формування й реалізації державної регіональної політики, європейської регіональної співпраці, зокрема у форматі транскордонного співробітництва та єврорегіонів.

Разом з тим актуальність проблематики транскордонного співробітництва в рамках Європейського континенту об'єктивно посилюється вже для третіх країн та держав, що проголосили та легалізували в конституції свій європейський вибір, до яких відноситься і Україна.

Тому метою даної статті виступає дослідження феноменології транскордонного співробітництва та його роль у функціонуванні «Європи регіонів».

Викладення основного матеріалу. Необхідно зазначити, що наведена характерологія території держави, особливо території, що знаходиться на ії периферії та є прилежною до державного кордону з іноземною (іноземними) державою/державами, - не $\epsilon$ чимось особливим, бо вона $\epsilon$ характерною для більшості держав світу. Разом з тим, слід враховувати і негативні наслідки таких особливостей, що, насамперед, відображаються:

а) на достатньо низькому економічному потенціалі території та рівні її економічного розвитку (негативний економічний критерій. - Авт.);

б) на недостатньому життєвому рівні людей, що мешкають на такій території (негативний соціально-екзистенційний критерій. - Авт.);

в) на питаннях слабкої керованості таких територій, причому як у просторі, так і у часі (негативний управлінський критерій. - Авт.);

г) на питаннях здійснення на неї публічно-владних повноважень, включаючи і МСВ (критерій «анемічності» публічної влади. - Авт.).

Для виправлення наведених недоліків міжнародна спільнота держав, спираючись на свій багатовіковий досвід спільного існування, спілкування і співробітництва на всіх рівнях державно-правової реальності та з урахуванням ментально-людських відносин, винайшла універсальний засіб, що заснований на міжнародному співробітництві місцевих органів влади та територіальних общин периферійних територій держави, що $\epsilon$ суміжними $з$ аналогічними територіями іншої держави (держав), скерований на розвиток колаборації наведених суб'єктів з метою отримання мультиплікативного ефекту від їх полісемічної взаємодії та співробітництва на користь людині.

${ }^{1}$ Jachtenfuchs, M. (2001). The Governance Approach to European Integration. Journal of Common Market Studies, 39, 2, 247. 
Філософсько-діяльнісним концептом такого співробітництва стала модель «комунікативної взаємодії» (Л. Вітгенштейн, Дж. Остін, Хейр, С. Тулмін, Ю. Хабермас), що спрямована на інтегративне розуміння соціальної реальності, відповідно до якого здійснюється перегляд i оновлення класичного поняття раціональності, а також визначення масштабів критичної оцінки соціального устрою,- результатом чого, є його перебудова на основі деліберативної розробки (публічного дискурсу) консенсусу між учасниками взаємодії (діалогу, полілогу тощо) ${ }^{1}$.

Управлінською основою такої взаємодії стало гасло «співробітництво заради розвитку», яке наочно демонструє як стратегічні телеологічні домінанти такої взаємодії між суб'єктами - органами публічної влади та фізичними особами іноземних держав, так і детермінує нормативні настанови щодо іiі побудови, умов організації, а також основоположні форми такої організаційної та організаційно-правової реалізації.

Саме така форма міжнародного співробітництва місцевих органів публічної влади - фактично органів місцевого самоврядування (далі - ОМСВ) та місцевих органів виконавчої влади суміжних держав, а також локальних територіальних людських спільнот (ТГ), що мешкають на керованих такими органами публічної влади територіях, - отримала назву транскордонного співробітництва. В парадигмальному розумінні в основі такого співробітництва лежать:

-по-перше, бажання підвищити рівень соціально-економічного, культурного, екологічного забезпечення прав і свобод людини, iï асоціацій - груп і колективів, що функціонують на суміжних прикордонних територіях держав (критерій антропологічної первинності та захищеності. - Авт.);

- по-друге, об’єктивація депресивного стану прикордонних (трансграничних) територій та їх занедбаність, особливо в економічному та соціальному розвитку (критерій визнання негативного локального розвитку. - Авт.);

-по-третє, об'єктивне прагнення до встановлення міжнародного співробітництва між наведеними територіями з метою поліпшення їх стану на засадах визначення відповідних телеологічних домінант такого розвитку та надання йому сталості, ефективного та передбаченого характеру (критерій визнання теологічної домінанти у вигляді міжнародного локального комплексносистемного співробітництва на засадах колаборації. - Авт.);

- по-четверте, усвідомлення і використання могутнього колабораційного потенціалу населення транскордонних територій суміжних держав, що мають загальний історичний, географічний, ментальний, мовний, соціальний дискурс (критерій використання ідентифікаційних локальних ресурсів, що є в наявності. - Авт.);

- а з часом, по-п’яте, і використання потенціалу транскордонної співпраці у відносинах населення вже не суміжних держав, з метою вирішення актуальних питань економічного, соціального, культурного розвитку, питань екологічного стану територій тощо (критерій модифікації і розширення принципу транскордонного співробітництва на периферійні території та публічні влади суверенних суб'єктів, що не є географічно суміжними, i більш широкого використання при цьому функціонально-номосних принципів субрегіоналізації та регіоналізації. - Авт.);

-по-шосте, формування і прояв могутньої тенденції інтерсуб'єктивності, що в умовах глобалізації, сприяє виникненню у народів суміжних і несуміжних держав загального розуміння екзистенційних настанов існування і функціонування в умовах демократичної правової державності на основі загальних людських цінностей та пошуку загальних шляхів вирішення проблем виживання людства (критерій становлення принципу інтерсуб'єктивності на субрегіональному та регіональному рівнях функціонування публічної влади держав-учасників макротранскордонного співробітництва. - Авт.);

- по-сьоме, побудова такого транскордонного співробітництва через активне використання найбільш наближеного до населення рівня публічної влади - ОМСВ або місцеві органи виконавчої влади, а також із залученням до такого співробітництва первинної локальної територіальної людської спільноти - ТГ (общини, колективу тощо) та інших суб'єктів, що існують та функціонують на їі території (критерій стабілізації та наступного розширення суб'єктної ознаки транскордонного співробітництва. - Авт.).

У контексті історичної ретроспективи наведені процеси, що згодом набули сили субрегіональних та регіональних тенденцій, у темпоральному вимірюванні збіглися з активізацією процесів деструктивності та нівелювання державного суверенітету в Свропі. Вони, насамперед,

\footnotetext{
${ }^{1}$ Мелкевик, Б. (2018). Юрген Хабермас и коммуникативная теория права. Санкт-Петербург: Алеф-Пресс, 21.
} 
були детермінованими ще Першою світовою війною і проявилися особливо яскраво і бурхливо в умовах Версальської системи - наслідком чого став крах чотирьох імперій: Німецької, АвстроУгорської, Оттоманської та Російської, що призвело до виникнення нових держав 3 достатньо проблемними державними кордонами, що були необгрунтованими історично, етнічно, економічно і політично, але зробленими на основі суб'єктивного підходу. Друга світова війна, своєю чергою, і наступне протистояння військово-політичних блоків НАТО і Варшавського Договору певною мірою «заморозили» ситуацію та відстрочили ії негативні для національної держави наслідки, закріпивши державні кордони, що склалися після завершення військового протистояння, i легалізувавши їх за результатами Наради з безпеки і співробітництва в Свропі (Хельсінкі, 1975). Однак розпад біполярної системи світу внаслідок припинення існування Союзу РСР та розпаду системи іiі держав-сателітів - «світової системи соціалізму», викликав істотні і стратегічні зміни в параметрах та «темпоральних швидкостях» загальноєвропейського розвитку. Отже, проблема державного суверенітету стала предметом не тільки обговорення, а й актуальним суб'єктомоб'єктом зовнішньополітичної та зовнішньоекономічної практики, причому не тільки на державному і асоційованому рівні (в рамках міждержавних інтеграційних об'єднань), а й на рівні регіональних утворень.

Звідси процес регіоналізації, особливо в умовах посилення європейських інтеграційних тенденцій, що були детермінованими діяльністю Ради Європи (далі - РЄ) та Європейського Союзу (далі - СС) набув нових організаційних, управлінських, ресурсних та перспективно-діяльнісних імпульсів. Тут ідеться не тільки про підвищення ролі регіонів в архітектурі європейського континенту, що розглядався як «загальноєвропейський дім», в розвитку європейської інтеграції та загальноєвропейському співробітництві, яке в попередні десятиліття гальмувалося жорстким протистоянням двох соціально-політичних систем, - мова йде, по-перше, про суттєве підвищення ініціативної ролі регіонів в загальноєвропейському будівництві,- особливо в контекстуалізації набуття ними більшої самостійності в умовах зростання їх національного і загальноєвропейського компетенційно-повноважного сегменту в управлінні територіями, включаючи і локальний фактор, i, по-друге, - про більш доступний вихід на достатньо солідні в кількісному вимірюванні матеріальнофінансові ресурси загальноєвропейських інтеграційних та континентальних банківських інституцій з метою детермінації сталого розвитку їх територій.

Треба наголосити на тому, що взаємозалежність сучасного глобалізованого світу зумовила високий ступінь спільності та синергічність цього процесу як для Західної, Центральної та Східної Європи, так і для України. У той же час, і це треба констатувати, - кожен окремий європейський регіон за власним баченням свого розвитку реагує на виклик часу. Це породжується, насамперед, об'єктивно існуючими в історичному вимірі, реально осмисленими і праксеологічно проявленими національними, культурними, історичними, геополітичними, правовими, соціальними та економічними особливостями регіону.

Отже, треба зазначити, що саме на вказаних особливостях будується регіональна політика європейського регіону, що детермінує суттєві зміни європейської інтеграційної політики та національних політик як держав-членів інтеграційних об'єднань, так і третіх держав. Звідси зростає роль і значення дослідження проблематики, з якою в даному контексті стикаються європейські демократичні держави, в основі якої лежить принцип «Європа регіонів», що в сучасних умовах світового розвитку набуває все більш суттєвого праксеологічного значення.

Наведене гасло-принцип «Європа регіонів» виступає термінологічним поняттям, яке:

-по-перше, формується та виникає внаслідок кризи держави-нації. Недарма Радник Державного департаменту США Дж. Ньюхауз вважає, що «масштаби держави-нації занадто великі для того, щоб вона могла керувати повсякденними проблемами, але занадто малі для того, щоб управляти справами міжнародними» ${ }^{1}$;

-по-друге, стає закономірним результатом глобалізації економіки і розвитку інтеграційних процесів; а,

- по-третє, стає одночасно і об'єктивним результатом осмислення локально-регіональними елітами своєї ролі та значення в регіональному розвитку і пробудження їх домагань до участі в державотворчих процесах;

\footnotetext{
${ }^{1}$ Newhouse, J. (1997). Europe's Rising Regionalism. Foreign Affairs, 76, 1

$<$ https://www.foreignaffairs.com/articles/europe/1997-01-01/europes-rising-regionalism> (2021, березень, 14).
} 
-по-четверте, демонструє об'єктивне підвищення соціально-політичної активності населення відповідних територій держави, що об'єднані в локальні територіальні людські спільноти, а також загострення «локальної етнічності», що була нівельована під впливом науково-технічної революції.

Треба зазначити, що активними суб'єктами всіх цих процесів, що розгортались на фоні правової глобалізації, стали як субнаціональні регіони, що були легалізовані та легітимізовані адміністративнотериторіальним поділом багатьох держав (департаменти у Франції, федеральні землі в Німеччині, області в Італії, графства у Великій Британії, фюльке в Норвегії, кантони в Швейцарії та ін.), так і регіони, які було утворено в результаті «транскордонного» співробітництва. Отже, треба констатувати, про виникнення в рамках руху «Європа регіонів» якісно нової соціально-політичної та нормативно-правової реальності, в умовах якої параметри компетенційної спроможності національних урядів зазнають суттєвих змін в бік скорочення, а регіони все настійніше вимагають не тільки більшого об'єму самоврядних повноважень всередині держави, а і самостійного виходу на міжнародну арену як суб’єктів міжнародних відносин, а в перспективі - як суб'єктів загального міжнародного права (причому, як публічного, так і приватного). Це особливо наочно проявляється в області інформації, нових технологій, ноу-хау, наукових досліджень.

Крім того, розширення компетентних можливостей регіонів детермінується і відповідною слабкістю центральних урядів щодо об'єктивної можливості управління в умовах перманентно зростаючої «прозорості» кордонів. На думку Т. Зонової, саме в урядів виходить 3-під їх контролю мобільністю капіталу, трудових ресурсів, товарів, культурних цінностей. Не тільки на державному рівні, а й на рівні інтеграційних об'єднань стає все складніше регулювати вплив транснаціональних корпорацій, чия могутність нерідко перевершує можливості урядів країн, на території яких розгортається їхня діяльність. Інші міжнародні економічні, торговельні та фінансові організації, що діють в системі світового і європейського ринків, спрямовуються до зламу протекціоністських бар'єрів і безпосередньому, іноді безконтрольного, взаємодії з споживачем. Постійним головним болем стає проблема організованої злочинності, наркоторгівлі, тероризм ${ }^{1}$.

Отже, передача наведених вище сфер на більш низький управлінський рівень - регіональний, може об'єктивно сприяти підвищенню управлінської ефективності та результативності у регулюванні цих складних міжнародних відносин у відповідних сферах. Звідси можна констатувати, що набуття регіонами, в тому числі й транскордонними, повноважень у наведених сферах буде не тільки сприяти активізації транскордонного співробітництва, а і становленню його нових форм, бо частину отриманих фінансів від управління в таких сферах зазвичай буде скеровано на потреби регіонального та локального розвитку.

Треба зазначити, що в процесі європейської інтеграції та становлення європейського регіоналізму досить чітко позначилися ще два фактори підвищення ролі регіональних утворень, причому як в межах держав-членів СС, так і всього Співтовариства.

3 одного боку, зросло та зміцнилося стійке усвідомлення того, що «органи місцевого самоврядування складають одну з основ демократичного ладу, забезпечуючи право громадян на участь в управлінні державними справами, що, своєю чергою, $є$ значним внеском у розбудову Європи, заснованої на принципах демократії і децентралізації влади». Більше того, це знайшло своє закріплення на міжнародно-правовому рівні в Преамбулі Європейській Хартії місцевого самоврядування 1985 року2 $^{2}$ що була прийнята Радою Європи - найбільшою міжнародною міжурядовою організацією континенту, до якої входять 47 держав-членів ${ }^{3}$.

А $з$ іншого боку, виникли тенденції дихотомічної властивості, що створили відповідне кризове становище - почались активні відцентрові процеси, в яких провідну роль відігравали органи публічної влади на рівні регіонів, тобто такі органи, що були максимально наближеним до громадян рівнем публічної влади, і це - стало оптимальним рішенням по виходу з кризи, бо об'єктивно виник соціально-нормативний простір, в межах якого як «субнаціональні», так і «транскордонні» регіони набули більшої ваги i значення. Вирішенню цієї кризи сприяла увага, яку Європейське Співтовариство, а потім і реформований з нього Свропейський Союз (1992 рік), приділяли регіональній політиці. Про неї як загальноєвропейський феномен почали говорити з 1969 року, коли

\footnotetext{
1 Зонова, Т. В. (1999). От Европы государств к Европе регионов. Полис, 5, 155.

2 Європейська Хартія місиевого самоврядування, 1985 (Рада Свропи). Офіиійний сайт Верховної Ради України <https://zakon.rada.gov.ua/laws/show/994_036\#Text> (2021, березень, 14).

${ }^{3}$ Council of Europe (2021). Homepage <https://www.coe.int/en/web/portal/home> (2021, березень, 14).
} 
3'явився документ Комісії $Є С$ «Регіональна політика Співтовариства» ${ }^{1}$. У ньому вперше містилася пропозиція «приступити до організації діяльності Товариства 3 питань регіонального розвитку», що фактично означало початок багатопланової діяльності, спрямованої на максимальний розвиток індустріальних регіонів, зміцнення зв'язків між ними і відсталими в промисловому відношенні районами, а також на створення полюсів розвитку в переважно сільськогосподарських зонах.

Стратегічним напрямком діяльності Комісії СС у цій сфері було шляхом «регіональної політики» і за допомогою фонду регіонального розвитку Товариства привести до економічного та соціального «вирівнювання» регіонів. Особливої актуальності це питання набуло узв'язку із розширенням СС спочатку за рахунок вступу до нього держав, що в економічному оцінюванні були слабко розвиненими, - Іспанії, Португалії та Греції, а потім й інших країн, окремі регіони яких потребували доволі солідних фінансово-ресурсних вливань. У цьому контексті необхідно зауважити, що в статтях витрат Спільноти саме Фонд регіонального розвитку посідав друге місце після фінансування її аграрної політики.

Нові - організаційний, нормативний та суттєвий міжнародно-правовий імпульси європейська регіональна політика набула приблизно з середини 80-х років XX ст., коли Рада Європи в 1980 році прийняла Європейську (Мадридську) рамкову конвенцію про транскордонне співробітництво між територіальними общинами або властями ${ }^{2}$, а в 1985 році- Європейську хартію місцевого самоврядування.

Прийняття міжнародно-правового акту профільної спрямованості, хоча і регіонального значення, стало, по-перше, свідоцтвом міжнародної міждержавної легалізації профільного виду співробітництва - транскордонного (легалізаційний фактор. - Авт.); по-друге, враховуючи його рамковий характер, ідентифікувало та визначило зобов'язання держав-підписантів щодо відтворення узятих міжнародно-правових настанов по міжнародному договору у національному конституційному законодавстві (облігаторний фактор. - Авт.); по-третє, визначило його суб’єктний склад - ОМСВ (місцеві органи виконавчої влади) та територіальні громади (суб'єктний фактор. - Авт.); почетверте, визначило об'єктний склад співробітництва - багатофакторне міжнародне співробітництво між вказаними суб'єктами різних спочатку суміжних, а потім і інших держав на основі: а) типових міждержавних угод про транскордонне співробітництво на регіональному та місцевому рівнях; а також б) угод, договорів та статутів про основні принципи співробітництва, які можуть бути основою для транскордонного співробітництва між територіальними общинами або органами влади (об' єктний фактор. - Авт.); no-n'яте, зафіксувало психологічну основу - «дух» такого співробітництва на засадах комунікативної взаємодії та колаборації (комунікативно-колабораційний фактор. - Авт.); по-шосте, визначила і контекстуалізувала на рівні міждержавних угод магістральні організаційноправові форми взаємодії між суб'єктами таких угод - про розвиток транскордонного співробітництва, про регіональні або місцеві зв'язки, про транскордонне співробітництво на контрактній основі між місцевими органами влади, про органи транскордонного співробітництва між місцевими органами влади (організаційно-правовий фактор. - Авт.); по-сьоме, визначила і закріпила формалізований та предметно-засадничий підхід до кола угод, статутів та договорів щодо основних принципів співробітництва між місцевими органами влади, а саме, - угод : а) про основні принципи створення групи зв'язку між місцевими органами влади; б) про основні принципи координації управління транскордонними місцевими державними справами; в) про основні принципи створення транскордонних асоціацій приватного права; договорів: а) про основні принципи поставки товарів або надання послуг між прикордонними місцевими общинами (типу «приватне право»); б) про основні принципи поставки товарів або надання послуг між прикордонними місцевими общинами (типу «публічне право»); в) про основні принципи створення органів транскордонного міжобщинного співробітництва (предметно-засадничий фактор. - Авт.).

Тобто, можна констатувати, що в основі наведеного нормативно-змістовного та технологічного підходів до регламентації та регулювання транскордонного співробітництва закладено засади мережевої взаємодії, що в процесі реалізації надають таким формам взаємодії якісно нових вад. Справа в тому, що у своєму функціональному розумінні мережі є рухливі і адаптивні, вони мають

\footnotetext{
${ }^{1}$ Региональная политика ЕС: сборник документов (2010). Региональная политика Сообщества: документ Комиссии Европейского Сообщества 1969 года.

${ }^{2}$ Свропейська рамкова конвенція про транскордонне співробітництво між територіальними общчинами або властями, 1980 (Рада Європи). Офіиійний сайт Верховної Ради Украйни <https://zakon.rada.gov.ua/laws/show/ 995_106\#Text> (2021, березень, 14).
} 
значні трансформаційні та адаптивні переваги перед ієрархічними формами, децентралізуючи виконання задач і розподіляючи процес прийняття рішень. Хоча, безсумнівно, у них є складнощі в координуванні функцій, в концентрації ресурсів і управлінні вирішенням складних завдань, які виходять за рамки мереж. У той же час, як вважає М. Кастельс, вони мають безпрецедентні можливості в подоланні цих складнощів ${ }^{1}$.

Використовуючи термінологічну зв'язку «мережеве суспільство», М. Кастельс бачить перед собою дві телеологічні домінанти: по-перше, багатопланово продемонструвати визначальну роль комп'ютерних інформаційних мереж у розвитку сучасного суспільства; по-друге, щоб показати, що реалії сучасного життя - це розвиток нових інформаційних технологій, зміна способів виробництва, використання виробничих відносин нового типу,- які неминуче ведуть до зміни і перетворення суспільних відносин. На думку Кастельса, в сучасному світі мережеві принципи суспільного устрою поступово змінюють ієрархічні: якщо раніше мережа, мережева організація була відображенням лише внутрішньої структури суспільства, iї підсистем та об'єднань, такою, що часто є невидимою, або такою, що важко розпізнається, то в новітньому світоустрою вона грає ключову роль і стає свідомо впроваджуваною зовнішньою структурою суспільства, ऑї формою2.

Отже, досліджуючи нову соціальну структуру, яка виявляється на нашій планеті в різних формах в залежності від різноманітності культур і інститутів, М. Кастельс приходить до висновку, що вона перш за все пов'язана із виникненням інформаційної, мережевої та глобальної економіки, історично сформованої перебудовою капіталістичного способу виробництва до кінця XX в. Терміном «інформаційна економіка» М. Кастельс підкреслює, що для сучасної економіки інформація не просто архіважлива, бо вона фактично виступає фундаментальним джерелом продуктивності і влади. Ця соціальна структура, що має електронну основу, на думку Кастельса, динамічна і відкрита для інновацій, не ризикуючи при цьому втратити свою збалансованість. Характерною ознакою суспільства мережевих структур Кастельс також вважає домінування соціальної морфології над соціальною дією, так як приналежність до тієї чи іншої мережі виступає в якості одного з найважливіших джерел влади і змін в сучасному суспільстві. Нова реальність являє собою «простір потоків», який складається з персональних мікромереж, де реалізація інтересів здійснюється через глобальну безліч взаємодій в функціональних макромережах. Під потоками М. Кастельс розуміє цілеспрямовані, повторювані послідовності взаємодій між соціальними акторами, що обмінюються різними типами ресурсів (капіталом, інформацією, технологіями, зображеннями, звуками і символами $)^{3}$.

Наведені аргументи М. Кастельса посилюються в процесі системного аналізу Європейської Хартії місцевого самоврядування 1985 року, що містить основоположні норми-принципи організації, втілення та компетенційних можливостей системи локальної демократії в межах демократичної правової державності. Виходячи з розуміння і тлумачення «простору потоків» Кастельса, ми бачимо не тільки цілеспрямовані, повторювані послідовності взаємодій між соціальними акторами (держава і органи публічної влади; місцеве самоврядування та його органи, місцеве самоврядування та територіальні громади, міжсуб'єктної взаємодія органів публічної влади, міжнародні контакти органів самоврядної публічної влади на міжсуб'єктному рівні та на рівні ОМСВ - міжнародна неурядова організація місцевої влади тощо), що дійсно інтенсивно та продуктивно будують відносини обміну різними типами ресурсів (включаючи капітал, інформацію, технології, форми життєдіяльності, методи комунікативної взаємодії тощо).

Висновки. Резюмуючи положення, що викладено вище, можна дійти наступних висновків:

-транскордонне співробітництво $\epsilon$ важливою формою загальноєвропейських процесів інтеграційного співробітництва, яка із самого початку була скерована на зрівнювання регіонів держав-членів Ради Європи в їхньому економічному і соціальному розвитку;

- зазначена форма співробітництва виникла, виходячи з особливостей історичного розвитку європейського континенту, результатів світових воєн та виникнення нових кордонів між державами, за їх підсумками, що фактично часто-густо порушували системні зв'язки між народами, які мешкали на територіях колишніх держав-імперій, але таких, що у своїй перспективі зберіглися в їх менталітеті,

\footnotetext{
${ }^{1}$ Кастельс, М. (2000). Информационная эпоха: экономика, общество, культура. Москва: ГУ ВШЭ. $<$ https://www.litres.ru/manuel-kastels/informacionnaya-epoha-ekonomika-obschestvo-i-kultura-24131802/> (2021, березень, 14).

2 Там само.

${ }^{3}$ Там само.
} 
національних, мовних, етнічних особливостях та характеристиках,- що сприяло актуалізації профільного співробітництва;

- транскордонне співробітництво займає суттєве місце та відіграє важливу роль у регіональній політиці Європейського Співтовариства, що було трансформовано в Європейський Союз, - більш того трансграничні регіони відіграють у такій політиці важливу інституційну роль, нарівні з субнаціональними регіонами держав-членів СС;

-в основі концепції «Европа регіонів» транскордонне співробітництво відіграє одну 3 найважливіших ролей, бо завдяки йому підвищуються і розширюється компетенційний потенціал не тільки прикордонних, а і субнаціональних регіонів, а також зростає міжнародна правосуб'єктність органів місцевого самоврядування держав-учасників транскордонного співробітництва;

- важливим елементом стабільного становлення і розвитку транскордонного співробітництва виступає його нормативна основа, яка дає змогу не тільки брати участь у його реалізації суміжним регіонам держав-членів $С$, а також і суміжним, а потім й іншим регіонам третіх країн, що виступають як держави-члени Ради Свропи та підписали Свропейську рамкову конвенцію про транскордонне співробітництво між територіальними общинами або владою 1980 року;

- прийняття Радою Європи в 1985 році Європейської Хартії місцевого самоврядування тільки посилило організаційні, нормативні, управлінсько-компетенційні та ресурсні можливості транскордонного співробітництва між територіальними общинами або властями в рамках європейського континенту;

- прийняття Радою Європи двох наведених міжнародно-правових актів договірного характеру не тільки легалізувало теоретико-праксеологічні наробки транскордонного співробітництва, a i сприяло легалізації основоположних принципів організації та функціонування інституту локальної демократії на теренах держав-членів цієї організації, що прискорило процеси його легітимації громадянами держав-членів СС (бо всі вони є одночасно і державами-членами Ради Свропи) і третіх країн, що заявили про своє бажання увійти до складу ЄС, вже будучи державами-членами Ради Європи;

-в умовах глобальної інформатизації транскордонне співробітництво між територіальними общинами або властями набуває характерологічних ознак системи, що заснована, функціонує та розвивається на засадах мережевої властивості, а це, своєю чергою, надає такому співробітництву: a) посилення його колабораційного потенціалу, б) залучення до такого виду співробітництва нових суб'єктів за межами його формального суб'єктного складу, що функціонують на територіях регіонів та місцевих влад, а також в) формування стійкого релятивістського потенціалу для розвитку і вдосконалення у реалізації його телеологічних домінант.

\section{References:}

1. Konstytutsiya Ukrayiny, 1996 (Verkhovna Rada Ukrayiny) [Constitution of Ukraine, 1996 (Verkhovna Rada of Ukraine)]. Vidomosti Verkhovnoyi Rady Ukrayiny [Information of the Verkhovna Rada of Ukraine], $30,141$. [in Ukrainian].

2. Busygina, I. M. (2001). Politicheskaya rol regionov v strukture Yevropeyskogo Soyuza: Kontseptualnyye i prikladnyye aspekty [The Political Role of Regions in the Structure of the European Union: Conceptual and Applied Aspects]: dissertatsiya na soiskaniye nauchnoy stepeni doktora politicheskikh nauk [dissertation for the degree of Doctor of Political Science]. Moscow: MGIMO MFA of Russia. [in Russian].

3. Lijphart, A., Karl, W. (1981). Deutsch and the New Paradigm in International Relations. In: Merritt, R., Russett, B. (eds) (1981). From National Development to Global Community. London, 233-251. [in English].

4. Jachtenfuchs, M. (2001). The Governance Approach to European Integration. Journal of Common Market Studies, 39, 2, 245-264. [in English].

5. Melkevik, B. (2018). Yurgen Khabermas i kommunikativnaya teoriya prava [Jurgen Habermas and the communicative theory of law]. SPb: Alef-Press. [in Russian].

6. Newhouse, J. (1997). Europe's Rising Regionalism. Foreign Affairs, 76, 1 <https://www.foreignaffairs.com/articles/europe/1997-01-01/europes-rising-regionalism> (2021, March, 14). [in English].

7. Zonova, T.V. (1999). Ot Yevropy gosudarstv k Yevrope regionov [From Europe States to Europe Regions]. Polis [Policy], 5, 155-164. [in Russian].

8. Yevropeyska Khartiya mistsevoho samovryaduvannya, 1985 (Rada Yevropy) [European Charter of Local SelfGovernment, 1985 (Council of Europe)]. Ofitsiynyy sayt Verkhovnoyi Rady Ukrayiny [European Charter of Local Self-Government, 1985 (Council of Europe). Official site of the Verkhovna Rada of Ukraine] <https://zakon.rada.gov.ua/laws/show/994_036\#Text> (2021, March, 14). [in Ukrainian]. 
9. Council of Europe (2021). Homepage <https://www.coe.int/en/web/portal/home> (2021, March, 14).

10. Regionalnaya politika YES: sbornik dokumentov (2010) [EU Regional Policy: Collection of Documents (2010)]. Regionalnaya politika Soobshchestva: dokument Komissii Yevropeyskogo Soobshchestva 1969 goda [Community Regional Policy: Document of the Commission of the European Communities 1969]. [in Russian].

11. Yevropeyska ramkova konventsiya pro transkordonne spivrobitnytstvo mizh terytorialnymy obshchynamy abo vlastyamy, 1980 (Rada Yevropy) [European Framework Convention on Transfrontier Co-operation between Territorial Communities or Authorities, 1980 (Council of Europe)]. Ofitsiynyy sayt Verkhovnoyi Rady Ukrayiny [Official site of the Verkhovna Rada of Ukraine] <https://zakon.rada.gov.ua/laws/ show/995_106\#Text> (2021, March, 14). [in Ukrainian].

12. Castells, M. (2000). Informatsionnaya epokha: ekonomika, obshchestvo, kultura [Information age: economy, society, culture]. Moscow: SU HSE. <https://www.litres.ru/manuel-kastels/informacionnaya-epoha-ekonomikaobschestvo-i-kultura-24131802/> (2021, March, 14). [in Russian]. 